\title{
Gymnema sylvestre (Gurmar): A Potent Herb with Anti-Diabetic and Antioxidant Potential
}

\author{
Suparna Laha, Santanu Paul*
}

\section{Suparna Laha, Santanu Paul*}

\author{
Laboratory of Cell and Molecular \\ Biology, Department of Botany, \\ University of Calcutta, Kolkata- 700019, \\ West Bengal, INDIA. \\ Correspondence \\ Dr. Santanu Paul \\ Laboratory of Cell and Molecular \\ Biology, Department of Botany, \\ University of Calcutta, 35 Ballygunge \\ Circular road, Kolkata 700019, \\ West Bengal, INDIA. \\ Phone no : +91 9874192648 \\ E-mail: spaul_1971@yahoo.com \\ History \\ - Submission Date: 06-09-2018; \\ - Review completed: 12-11-2018; \\ - Accepted Date: 03-01-2019.
}

DOI : 10.5530/pj.2019.11.33

\section{Article Available online}

http://www.phcogj.com/v11/i2

\section{Copyright}

(c) 2019 Phcog.Net. This is an openaccess article distributed under the terms of the Creative Commons Attribution 4.0 International license.

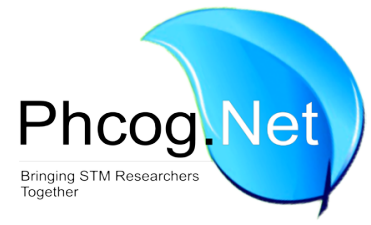

\begin{abstract}
Introduction: Diabetes Mellitus is a metabolic disorder with high blood sugar level. Type 2 is the common form. The herbal remedies for diabetes treatment is an area of research with a huge potential for the progress in the growth of inexpensive alternative medicine with low or no side effects. In this paper, reviews mainly focused on traditionally used medicinal herb, Gymnema sy/vestre and its bioactive components and their mode of actions. Method: Relevant information was collected from scientific journals, research papers, books and various medicinal reviews. Result: This review provides a comprehensive report on Gymnema sylvestre having antidiabetic and antioxidant activity due to its bioactive compounds like oleanines (Gymnemic acid, Gymnema saponins), dammarenes (Gymnemasides), anthraquinones, flavones, hentriacontane, pentatriacontane, phytin, resin, tartaric acid, formic acid, butyric acid, lupeol, $\beta$-amyrene related glycosides and anthraquinones, alkaloid like gymnamine, flavonoids, cinnamic acid, folic acid, ascorbic acid etc. Conclusion: Considering the presence of bioactive compounds present in Gymnema sylvestre, this review is aimed to summarize the information of the chemical constituents and their antidiabetic activities and specially to detect the relation between antioxidants and antidiabetic compounds regarding blood sugar reduction in diabetes.
\end{abstract}

Key words: Gymnema sylvestre, Alternative Medicine, Bioactive compounds, Anti- diabetic, Antioxidant.

\section{INTRODUCTION}

Type 2 Diabetes Mellitus is increasing alarmingly day by day. Starting from aged persons to young ones even children are also suffering from this epidemic disorder. Type 2 diabetes is a metabolic disorder which is characterised by hyperglycemia resulting from defective insulin secretion, resistance to insulin action or both. ${ }^{1-3}$ Hyperglycemia occurs when blood sugar levels become too high (above $200 \mathrm{mg} / \mathrm{dl}$ ). Some other factors like consumption of more carbohydrates than usual, less or no physical activity, being ill or having an infection, increase in stress, not getting proper dose of medicines etc. are also responsible for causing this. In early stage different symptoms like frequent urination, increased thirst, blurred vision, fatigue, headache, etc. are noticed. Later if untreated, other complications crop up like fruity-smelling breath, nausea, vomiting, shortness of breath, dry mouth, weakness, confusion, coma, abnormal activity. Long term damage of target organs like heart, kidney and nerves leading to cardiovascular complications, diabetic neuropathy (damage of nerve cells), kidney damage or Congestive Kidney Failure (CHF), diabetic retinopathy (damage of retinal blood vessels), cataract, diabetic foot infection, bone and joint problems etc. also develop. Generally, simple carbohydrate, Glucose formed from complex carbohydrates is directly absorbed into the bloodstream but cannot enter the body cells without the help of insulin.
Insulin plays a vital role in controlling high blood sugar level. Any defect in insulin production and action leads to serious metabolic disorders. Insulin in normal dose is not able to activate the cells to take up the glucose. So, they want more amount of insulin for cell's sensitization and thereby help to transport a special transporter, GLUT 4 and Hexokinase to the cell surface. GLUT 4 is found in adipose tissues and skeletal/cardiac muscles and is known to be responsible for the regulation of cellular glucose uptake upon stimulation caused by external factors, such as insulin and exercise. ${ }^{4-5}$

Various factors like Genetic factors, environmental factors, metabolic hormones (leptin, adiponectin, glucagon), excess nutrients, systemic free fatty acids, ER stress / oxidative stress, adipose hypoxia etc. play the role for generation of insulin resistance. Various chemical medications like insulin therapy, acarbose, miglitol (Alpha Glucosidase Inhibitors), metformin (Biguanides), dopamine agonist (Bromocriptine), DPP-4 inhibitors, glucagon like peptides, SGLT-2 inhibitors, etc. are used to cure this disease but due to their critical and deleterious complications and reported side-effects (skin rash, sickness with alcohol, kidney damage, gas, bloating, diarrhea, stomach upset, etc.) people are being scared to use it. ${ }^{6}$ 
Oxidative stress is also related with long term complications (development of vascular complications) of Type 2 diabetes. Oxidative stress is used to describe the high level of oxidative damage in a cell, tissue or organ, caused by the ROS (Reactive Oxygen Species) ${ }^{7}$ and imbalance between the Reactive species (RS) and antioxidants result in the development of Type 2. Oxidative stress in diabetes causes alteration in enzymatic systems, lipid peroxidation, impaired glutathione metabolism and low level of Vitamin C. ROS is responsible for damaging lipids, proteins and DNA, Glutathione, Catalase and Superoxide Dismutase (SOD) that are different types of bio-markers of oxidative stress in Diabetes Mellitus. Three factors are responsible for creating ROS like i) increasing oxidant generation, ii) lowering anti-oxidant protection and iii) failure to repair oxidative damage. Both ROS and RNS (Reactive Nitrogen Species) are types of free radicals which have got negative regulation on insulin signalling, interpreting them to develop insulin resistance which is a risk factor for Type 2 Diabetes. ${ }^{8}$ RNS has same type of functions as ROS like lipid peroxidation, non-enzymatic protein glycation and glucose oxidation. Keeping in mind of all above facts, researchers are involved in discovering of a new herbal product with features like its availability, cheaper cost and non-toxic in nature.

Gymnema sylvestre is an important herb in the treatment of Type $2 \mathrm{DM}^{9}$ due to the presence of oleanane, dammarane types of secondary metabolites and antioxidants like flavonoids, cinnamic acid, folic acid, ascorbic acid etc. along with potential health benefit ${ }^{10}$ and with fewer side effects ${ }^{11}$ or no effects. So, Gymnema can be used as an alternative medicine. ${ }^{12}$

\section{About Herbal Medicine}

Phyto-medicine or Botanical medicine is popularly called as "Herbal Medicine" because various plant parts like seeds, berries, roots, leaves, bark or flowers, etc. are used for medicine preparation. Use of herbal medicine is becoming popularized as up-to-date analysis and experimentation show their importance in the treatment and prevention of diseases due to their natural origin and less side effects. The World Health Organization (WHO) has listed 21,000 plants that are used for medicinal purposes throughout the world. It is validated in science due to its active phytochemical ingredients. Before herbal medicine preparation or formulation, herbalists must have necessary information about its cultivation, collections, processing, diagnosis, extraction of active phytochemicals, etc. India stands to become a significant and successful exporter of herbal crude extracts. Indian herbal market is providing a good source of income to both farmers and traders. For encouraging the use of herbs in developed countries, some precautions should be followed like well documentation about herbal medicine, single plant medicine free of pesticides, heavy metals, poisons and detrimental side effects. Herbal medicines should be of user friendly and with standardized chemical and activity profile.

\section{METHODOLOGY}

Data obtained from various sources like Research Gate, PubMed, Science Direct, etc. for studies focusing on the biological and pharmacological activities of Gymnema sylvestre. Different literature and review articles on Gymnema are studied about its phytochemical constituents and their antidiabetic and antioxidant activities, parts use, method of use, color, taste, duration of use, etc. The list of references of all relevant articles was also studied to include all reports and reviews related to the matter.

\section{Cultivation}

Gymnema sylvestre reproduces vegetatively through stem cuttings and sexually through seeds. Seeds are sown in the month of November and December and are harvested after 8-9 months. Seed viability is very short but their highest germination (92\%) is shown when sown in coir dust.
Improved agro techniques (in-vitro regeneration, cell culture) have been followed for their better cultivation.

\section{Geographic Distribution}

Gymnema sylvestre has worldwide distribution. It occurs from Africa east to Saudi Arabia, Vietnam, Sri Lanka, South China and from Japan to Philippines, Malaysia, Indonesia, Australia and in dry forests throughout India. ${ }^{13}$ In India, it is distributed in Banda, Konkan, Western Ghats and Deccan Peninsula extending to the parts of Western and Northern India.

\section{Traditional Use}

According to Sushruta, Gymnema sylvestre was used as sugar destroyer (due to chewing of leaves which destroys the ability to identify the sweet taste) in case of glycosuria and other urinary diseases. Various reports are obtained on its nature like bitterness, astringent, thermogenic activity, anti-inflammatory, digestive, liver tonic, diuretic, stomachic, stimulant, anthelmintic, laxative, cardio tonic, anti-pyretic and uterine tonic, etc. It is useful in dyspepsia, constipation, hepatitis, hemorrhoids, renal and vesicle calculi, cardiopathy, asthma, bronchitis, amenorrhea, conjunctivitis and leukoderm. ${ }^{14}$

\section{Bio Active Antidiabetic and Antioxidant Compounds Antidiabetic compounds}

In Gymnema sylvestre various secondary metabolites are present. Such metabolites are oleanane saponins and dammarane saponins. Oleanane saponins are of two types i.e. gymnemic acid (Figure 1) and gymnema saponins. Gymnemasaponins consists of two aglycone saponins like gymnemagenin and gymnestrogenin. ${ }^{15}$ (Figure 1). Dammarane saponins include gymnemasides (I-VII). ${ }^{16-17}$ All of these secondary metabolites have antidiabetic properties. Besides these triterpenoid saponins ${ }^{18-20}$ other antidiabetic constituents are anthraquinone, flavones, flavonoids ${ }^{21}$ like epicatechin, apigenin, luteolin, kaempferol,hentriacontane, pentatriacontane, phytin, resins, tartaric acid, formic acid, butyric acid, lupeol, $\beta$-amyrin related glycosides. ${ }^{22}$ Anthraquinones and their derivatives, alkaloids-conduritol, gymnamine, ${ }^{23-26} \alpha$ and $\beta$ chlorophyll, polypeptide (Gurmarin), ${ }^{27-28} \mathrm{~d}$-quercitol, stigmasterol, nonacosane, parabin, calcium oxalate, cellulose, lignin etc. also possess antidiabetic potential.

\section{Antioxidant compounds}

Flavonoids, tannins, alkaloids, phenols, cinnamic acid, folic acid, ${ }^{29}$ ascorbic acid, ${ }^{30-31}$ butyric acid, tartaric acid etc. type of antioxidants are present in Gymnema sylvestre.

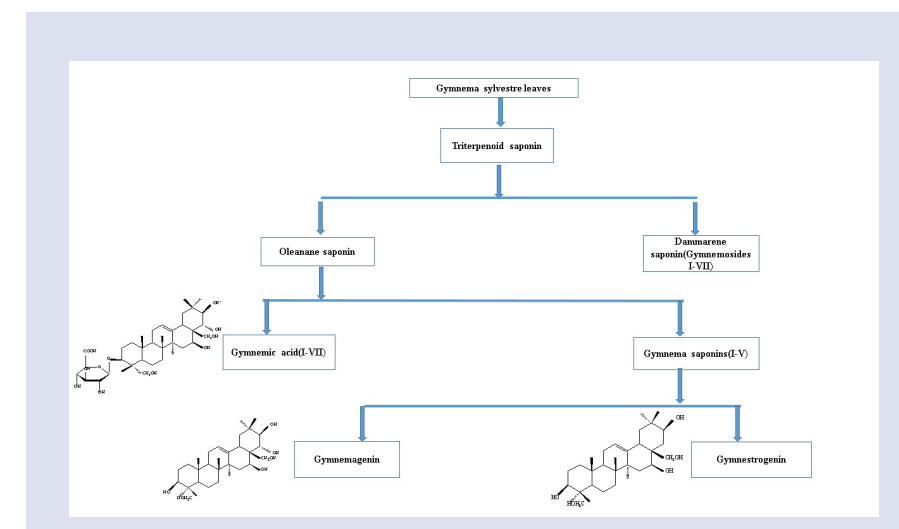

Figure 1: Chemical structure of the important bioactive molecules from Gymnema sylvestre. 


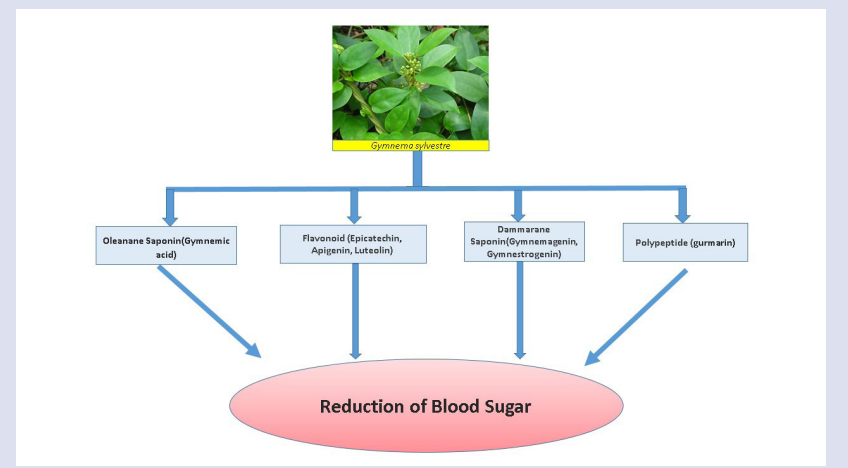

Figure 2: Blood sugar reduction potential of different biocomponents of Gymnema sylvestre.

\section{Chemical Structure of Bioactive Compounds}

In case of Gymnema sylvestre, gymnemic acids are triterpenoid glycosides. ${ }^{32-33}$ The central structure is aglycone gymnemagenin. This is adorned with a sugar such as glucoronic acid and with various ester groups. Gymnemic acid is not a pure, unique structure but is composed of several types of homologues or compounds of the same general formula. ${ }^{34-35}$ Gymnemic acid A comprises of A1, A2, A3 and A4. The aglycone gymnemagenin is a D-glucoronide of hexa-hydroxytriterpene. ${ }^{36}$

Gymnema saponin iii is another anti-sweet compound which consists of 23 hydroxy longispinogenin as the aglycone moiety. ${ }^{37}$

Another antidiabetic compound, dammarane is a tetracyclic tri-terpene saponin. Seven new dammarane saponins, named Gymnemasides i-vii have been isolated from leaves of Gymnema sylvestre, together with previously known dammarane type saponins, gypenoside XXVIII, XXXVII, LV, LXII, LXIII. ${ }^{38-39}$

Anti-oxidants such as Terpenoids are unsaturated hydrocarbons with oxygen containing functional group derived from terpenes. Flavonoids have 15 carbon skeleton structure that consists of two phenyl rings (A and $\mathrm{B})$ and heterocyclic $\operatorname{ring}(\mathrm{C})$. Cinnamic acid is white crystalline organic compound which is highly soluble in organic solvent. It is classified as an unsaturated carboxylic acid. Another antioxidant, folic acid also called as Vitamin B9, is white and crystalline compound. It is also known as phenolic acid or pteroglutamic acid. Tannins are esters of phenolic acid containing hydroxyl and carboxyl groups. Phenols are aromatic, white crystalline compounds where hydroxyl group is attached with carbon atom that is part of an aromatic ring.

\section{Essential Chemical Components of Gymnema sylvestre and its Mode of Action in Downregulating Blood- Glucose Level}

Proposed mechanism for the hypoglycemic action of gymnemic acid might be increased secretion of insulin from the pancreas and promotion of islet cell regeneration. ${ }^{40}$ Hypoglycemic effects of gymnemic acids are: i) it increases insulin secretion ii) it promotes regeneration of islets cells iii) it increases glucose utilisation, it is shown to increase the activities of enzymes responsible for utilisation of glucose by insulin dependent pathways, an increase in phosphorylase activity, decrease in gluconeogenic enzymes and sorbitol dehydrogenase. iv) It causes inhibition of glucose absorbtion from intestine. Gymnemic acid binds to the receptor on the intestine and stop glucose molecule from binding to the receptor and thus prevent excess glucose absorption. Gymnemic acid binds to
$\mathrm{Na}+$ glucose symporter in intestine thereby prevent glucose absorption (Figure 2).

In case of gymnemasaponins, anti-sweet activity is also developed due to the presence of Acyl group, so it is an aglycone part of saponin. It also increases the amount of insulin in blood plasma. Gymnemagenin has anti hyperglycemic activity. Gymnestrogenin's other antidiabetic activities still not observed from various literature. Antidiabetic activities of various bioactive components are very much essential for Type 2 diabetes control (Table 1). ${ }^{41-52}$

Antidiabetic compounds such as anthraquinone, flavones, flavonoids like epicatechin, Apigenin, Luteolin, Kampferol, Hentriacontane, Pentriacontane, Phytin, Resin, Lupeol, $\beta$-amyrene related glycosides, alkaloid (conduritol), $\alpha$ and $\beta$ - chlorophyll, Stigmasterol, d-quercitol, Nonacosane, Lignin etc. also have antioxidant activites.

Antioxidant like ascorbic acid neutralizes hydroxyl radicals, super oxide radicals thereby proving its antioxidant nature and also showing blood sugar uptaking abilities. Both antioxidant and antidiabetic function is very helpful in Type 2 diabetes treatment. Other antioxidants like Terpenoid, Flavonoid, Cinnamic acid, Folic acid, Tannin, Phenol etc. also perform antidiabetic as well as antioxidant activity.

As antidiabetic components of Gymnema show antioxidant activities vice versa antioxidants also show their antidiabetic potential (Table 2)..$^{53-58}$

\section{RESULT AND DISCUSSION}

Based on various scientific literature, it has been proved that Gymnema sylvetre is one of the most important herb with antidiabetic and anti-

Table 1: Table showing both antidiabetic and antioxidant compounds of Gymnema sylvestre and their mode of action.

\begin{tabular}{|c|c|c|}
\hline $\begin{array}{l}\text { BIO-ACTIVE } \\
\text { ANTI DIABETIC } \\
\text { COMPOUNDS } \\
\text { ISOLATED FROM } \\
\text { Gymnema sylvestre }\end{array}$ & MODE OF ACTION & REFERENCE \\
\hline Oleanane & Hypoglycemic activity. & 40 \\
\hline Gymnemic acid & $\begin{array}{l}\text { Reduction of blood sugar because } \\
\text { gymnemic acid molecules fill the } \\
\text { receptor location in the outer layer } \\
\text { of intestine, thereby preventing sugar } \\
\text { absorption in intestine. }\end{array}$ & 41 \\
\hline Gymnemasides (A-F) & $\begin{array}{l}\text { Inhibitory effects on increased level } \\
\text { of serum glucose. }\end{array}$ & $42-44$ \\
\hline $\begin{array}{l}\text { Gymnemic acid(I- } \\
\text { XVIII)homologue }\end{array}$ & $\begin{array}{l}\text { Sweetness inhibiting substances } \\
\text { present. }\end{array}$ & 45,46 \\
\hline $\begin{array}{l}\text { Gymnemic acidA1 } \\
\text { and its derivatives. }\end{array}$ & Antisweet activity. & 47,48 \\
\hline Triterpenoidsaponin & $\begin{array}{l}\text { Hypoglycemic and anti } \\
\text { hyperglycemic activity. }\end{array}$ & 49 \\
\hline $\begin{array}{c}\text { Alkaloid } \\
\text { (Conduritol-A) }\end{array}$ & Hypoglycemic & 50 \\
\hline $\begin{array}{l}\text { Polypeptide } \\
\text { (Gurmarin) }\end{array}$ & $\begin{array}{c}\text { Block the ability to sweet taste or } \\
\text { bitter flavours and thus reduces } \\
\text { sweet carvings. }\end{array}$ & 51 \\
\hline $\begin{array}{l}\text { Gymnemasaponins } \\
\text { (Gymnemagenin and } \\
\text { Gymnestrogenin) }\end{array}$ & $\begin{array}{l}\text { Hypoglycemic activity. B cell } \\
\text { regeneration. } \\
\text { Gymnemagenin inhibits glucose } \\
\text { absorption }\end{array}$ & 52 \\
\hline
\end{tabular}


Table 2: Table showing antioxidants of Gymnema sylvestre with their both antidiabetic and antioxidant activities.

\begin{tabular}{|c|c|c|}
\hline NAME OF COMPONENTS & $\begin{array}{l}\text { ANTI-OXIDANT AND } \\
\text { ANTIDIABETIC ACTIVITIES }\end{array}$ & REFERENCE \\
\hline Ascorbic acid & $\begin{array}{l}\text { Neutralise hydroxyl, superoxide } \\
\text { and hydrogen peroxide radicals. } \\
\text { Glucose uptake activity. Increase } \\
\text { insulin sensitivity to diabetic } \\
\text { patients. }\end{array}$ & 53,54 \\
\hline $\begin{array}{l}\text { Nonacosane, } \\
\text { hentriacontane, } \\
\text { pentatriacontane, } \alpha \text { and } \\
\beta \text { chlorophyll, phytin, } \\
\text { resin, d-quercitol, } \\
\text { formic acid, butyric acid, } \\
\text { tartaric acid, } \beta \text {-amyrene } \\
\text { related glycosides, } \\
\text { Anthraquinones and their } \\
\text { derivatives. }\end{array}$ & $\begin{array}{l}\text { Scavenging free radicals and } \\
\text { Glucose lowering activity. }\end{array}$ & 55,56 \\
\hline $\begin{array}{c}\text { Terpenoid, Flavonoid, } \\
\text { Cinnamic acid, Folic acid, } \\
\text { Tannin, Phenol. }\end{array}$ & $\begin{array}{l}\text { Scavenging SOD, } \mathrm{H}_{2} \mathrm{O}_{2} \text { and } \\
\text { having reducing power ability. } \\
\text { Reduction of blood glucose and } \\
\text { Glucose absorption in intestine. } \\
\text { Stimulation of insulin secretion } \\
\text { from } \beta \text { cell, glucose uptake and } \\
\text { Inhibition of } \alpha \text {-amylase and } \\
\text { a-glucosidase. }\end{array}$ & 57,58 \\
\hline
\end{tabular}

oxidant potential due to the prevalence of many bio components. Antioxidant activity is responsible for reducing the oxidative stress in cells therefore being useful in the treatment of many human diseases including diabetes. Diabetic patients remain under oxidative stress. So, use of antioxidants like flavonoids, phenolics can be beneficial for diabetic patients. Saponins regulate plasma glucose levels and prevent diabetic complications due to its antioxidant activity. Use of such antioxidants can also be used for management of noninsulin dependent diabetes mellitus by inhibiting $\alpha$-glucosidase and $\alpha$-amylase activity. As per various literature reviews, not so many research activities done on mode of actions of gymnemagenin and gymnestrogenin, so future research work must be done on these compounds.

\section{CONCLUSION}

Antidiabetic activity along with antioxidant potential of Gymnema sylvestre $\mathrm{R}$.Br have been reported till date due to the presence of flavonoids, phenols and various bioactive compounds like gymnemic acid, gymnemarerin and other secondary metabolites like saponins, tanins (phenolic compounds) and triterpenoids that are antioxidants but show antidiabetic activity also. So, we can conclude from various literature reviews that biocomponents possess both antidiabetic and antioxidant activities and antioxidants with their antidiabetic features also. As diabetes incidence increases day by day, more effective research and assessment or analysis must be required to find out other active phytochemical compounds with exact active antidiabetic mechanism of action for human welfare in near future.

\section{ACKNOWLEDGEMENT}

The Authors are indebted to UGC-UPE and UGC-CAS programme at the Department of Botany, University of Calcutta for financial support.

\section{CONFLICT OF INTEREST}

There is no conflict of interest.

\section{ABBREVIATIONS}

GLUT: Glucose transporter; DPP: Dopamine Pyro Phosphate; ROS: Reactive Oxygen Species; RS: Reactive Species; SOD: Superoxide Dismutase; RNS: Reactive Nitrogen Species.

\section{REFERENCES}

1. Jarald E, Joshi SB, Jain DC. Diabetes and herbal medicines. Iranian J Pharmaco Ther. 2008;7(1):97-106.

2. Vasi S, Austin A. Effect of herbal hypoglycemic on oxidative stress and antioxidant status in diabetic rats. The Open Diabet. 2009;18(2):48-52.

3. Khan V, Najmi AK, Akhtar M, Aqil M, Mujeeb M, Pillai KK. A pharmacological appraisal of medicinal plants with antidiabetic potential. J Pharm Bioall Sci. 2012;4(1):27-42.

4. Mitsumoto Y, Klip A. Development regulation of the subcellular distribution and glycosylation of GLUT1 and GLUT4 glucose transporters during myogenesis of L6 muscle cells. J Biol Chem.1992;267(7):4957-62.

5. Kumar PM, Venkataranganna MV, Manjunath K, Viswanatha GL, Ashok G. Methanolic leaf extract of Gymnema sylvestre augments glucose uptake and ameliorate insulin resistance by up regulating glucose transporter-4, peroxisome proliferator activated receptor gamma, adiponectin and leptin levels invitro. Journal of Intercultural Ethnopharmacology. 2016;5(2):146-52.

6. Patil PM, Chaudhari PD, Duragkar NJ, Katolkar PP. Formulation of anti-diabetic liquid preparation of Gymnema sy/vestre and qualitative estimated by TLC. Asian Journal of Pharmaceutical and Clinical Research. 2012;5(Supplement 1):16-9.

7. Johansen SJ, Harris KA, Rychly JD, Ergul A. Oxidative stress and the use of antioxidants in diabetes. Cardiovas Diabetol. 2005;4(1):5

8. Erejuwa OO. Management of diabetes mellitus: Could simultaneous targeting of hyperglycemia and oxidative stress be a better panacea?. Int J Mol Sci. 2012;13(3):2965-72

9. Pothuraju R, Sharma RK, Chagalamarri J, Jangra S, Kumar KP. A systematic review of Gymnema sylvestre in obesity and diabetes management. J Sci Food Agric. 2014;94(5):834-40.

10. Zhao JQ, Wang YM, Yang YL, Zeng Y, Mei LJ, Shi YP, et al. Antioxidants and a -glucosidase inhibitors from "Liucha" (young leaves and shoots of Sibiraea laevigata). Food Chem. 2017;230:117-24

11. Sujin RM, Subin RM, Mahesh R, Mary RVJ. Antidiabetic effects of Gymnema sylvestre (Asclepiadaceae) powder in the stomach of rats. Ethnobotanical Leaflets. 2008;2008(1):158-67.

12. Kishore L, Kaur N, Singh R. Role of Gymnema sylvestre as alternative medicine. J Homeop Ayurv Med. 2014;3(4):172-80.

13. Srivastava JL, Tiwari KP, Sharma MC. Ruby Medicinal plants of Madhya Pradesh: immediate need of conservation. J Trop For. 1999;15(2):144-51.

14. Joy PP, Thomas J. Kerala Agriculture University Aromatic and Medicinal plant research station Odakkali. Asamannoor PO Ernakulam District, Kerala, India. 1998;16.

15. Rao GS, Sinsheimer JE. Constituents from Gymnema sylvestre leaves. 8. Isolation, chemistry and derivatives of gymnemagenin and gymnestrogenin. Journal of Pharmaceutical Sciences. 1971;60(2):190-3

16. Yoshikawa $M$, Murakami $T$, Kadoya $M$, et al. Medicinal foodstuffs. IX. The inhibitors of glucose absorption from the leaves of Gymnema sylvestre R.Br. (Asclepiadaceae): structures of gymnemosides A and B. Chemical and Pharmaceutical Bulletin. 1997;45(10):1671-6.

17. Yoshikawa K, Arihara S, Matsuura K, Miyaset T. Dammarane saponins from Gymnema sylvestre. Phytochemistry. 1992;31(1):237-41.

18. Suttisri R, Lee IS, Douglas KA. Plant-derived triterpenoid sweetness inhibitors Journal of Ethnopharmacology. 1995;47(1):9-26.

19. Sahu NP, Mahato SB, Sarkar SK, Poddar G. Triterpenoid saponins from Gymnema sylvestre. Phytochemistry. 1996;41(4):1181-5.

20. Yendo ACA, De Costa F, Gosmann G, Fett-Neto AG. Production of plant bioactive Triterpenoid saponins: elicitation strategies and target genes to improve yields. Molecular Biotechnology. 2010;46(1):94-104.

21. Liu X, Ye W, Yu B, Zhao S, Wu H, Che C. Two new flavonol glycosides from Gymnema sylvestre and Euphorbia ebracteolata. Carbohydrate Research. 2004;339(4):891-5.

22. Shibuya $M$, Katsube $Y$, Otsuka $M$, et al. Identification of a product specific $\beta$-amyrin synthase from Arabidopsis thaliana. Plant Physiology and Biochemistry. 2009;47(1):26-30.

23. Yoshikawa K, Nakagawa M, Yamamoto R, Arihara S, Matsuura K. Antisweet natural products. V. Structures of gymnemic acids VIII-XII from Gymnema sylvestre R.Br. Chemical and Pharmaceutical Bulletin. 1992;40(7):1779-82.

24. Chakravarti D, Debnath NB. Isolation of gymnemagenin the sapogenin from Gymnema sylvestre R.Br. (Asclepiadaceae). Journal of the Institution of Chemists. 1981;53:155-8

25. Rao GS, Sinsheimer JE. Constituents from Gymnema sylvestre leaves VII. 
3p,23; 16p, 28-di-O-isopropylidene derivative of gymnemagenin. Journal of Chemical Society. 1970;13;1823-5.

26. Zhen HS, Zhu XY, Lu RM, Liang J, Qiu Q, Meng OM. Research on chemical constituents from stem of Gymnema sylvestre. Journal of Chinese Medicinal Materials. 2008;31(8):1154-6.

27. Imoto T, Miyasaka A, Ishima R, Akasaka K. A novel peptide isolated from the leaves of Gymnema sylvestre - I. Characterization and its suppressive effect on the neural responses to sweet taste stimuli in the rat. Comparative Biochemistry and Physiology. 1991;100(2):309-14.

28. Arai K, Ishima R, Morikawa S, et al. Three-dimensional structure of gurmarin, a sweet taste-suppressing polypeptide. Journal of Biomolecular NMR. 1995;5(3):297-305

29. Kang MH, Lee MS, Choi MK, Min KS, Shibamoto T. Hypoglycemic activity of Gymnema sylvestre extracts on oxidative stress and antioxidant status in diabetic rats. Journal of Agricultural and Food Chemistry. 2012;60(10):2517-24.

30. Rose RC, Bode AM. Biology of free-radical scavengers - An evaluation of ascorbate. FASEB J. 1993;7(12):1135-42.

31. Rachh PR, Rachh MR, Ghadiya NR, et al. Antihyperlipidemic Activity of Gymnema sylvestre R. Br. Leaf extract on Rats Fed with High Cholesterol diet. Int J Pharmacol. 2010;6:138-41.

32. Yoshikawa K, Amimoto K, Arihara S, Matsuura K. Gymnemic acid V, VI and VII from gur-ma, the leaves of Gymnema sylvestre R.Br. Chemical and Pharmaceutical Bulletin. 1989;37(3):852-4.

33. Manohar SH, Naik PM, Praveen N, Murthy HN. Distribution of gymnemic acid in various organs of Gymnema sylvestre. Journal of Forestry Research. 2009;20(3):268-70.

34. Baskaran K, Ahamath BK, Shanmugasundaram KR, Shanmugasundaram ERB. Antidiabetic effect of a leaf extract from Gymnema sylvestre in noninsulin-dependent diabetes mellitus patients. Journal of Ethnopharmacology. 1990;30(3):295-305

35. Nakamura $Y$, Tsumura $Y$, Tonogai $Y$, Shibata T. Fecalsteroid excretion is increased in rats by oral administration of gymnemic acids contained in Gymnema sylvestre leaves. J Nutr. 1999;129(6):1214-22.

36. Tiwari P, Mishra BN, Sangwan NS. Phytochemical and Pharmacological Properties of Gymnema sylvestre: An Important Medicinal Plant. Biomed Res Int. 2014;2014

37. Yoshikawa K, Amimoto K, Arihara S, Matsuura K. Structure studies of new antisweet constituents from Gymnema sylvestre. Tetrahedron Letters. 1989;30(9):1103-6.

38. Yoshikawa K, Amimoto K, Arihara S, Matsuura K. Gymnemic acid V, VI and VII from gur-ma, the leaves of Gymnema sylvestre R.Br. Chemical and Pharmaceutical Bulletin. 1989;37(3):852-4.

39. Sinsheimer JE, Subbarao G. Constituents from Gymnema sylvestre leaves VIII: Isolation, chemistry and derivatives of gymnemagenin and gymnestrogenin. J Pharm Sci. 1971;60(2):190-3.

40. Stoecklin W. Glycosides and aglycons. CCCIX. Gymnestrogenin. A new pentahydroxy triterpene from Gymnema sylvestre leaves. Helvetica Chimica Acta. 1968:51(6):1235-42.

41. Stoecklin W, Weiss E, Reichstein T. Glycosides and aglycons. CCLXXXVIII Gymnemic acid, the antisaccharin principle of Gymnema sylvestre-Isolation and identification. Helvetica Chimica Acia. 1967;50(2):474-90.

42. Kazuko Y, Yuuji K, Shigenobu A, Kouji M, Toshio M, Liu HM, et al. Dammarane saponins from G. sylvestre. Phytochemistry. 1992;31(1):237-41.
43. Yoshikawa M, Murakami T, Kadoya M, et al. Medicinal foodstuffs. IX. The inhibitors of glucose absorption from the leaves of Gymnema sylvestre R.Br. (Asclepiadaceae): structures of gymnemosides A and B. Chemical and Pharmaceutical Bulletin. 1997;45(10):1671-6

44. Yoshikawa K, Murakami T, Matsuda H. Medicinal food stuffs X1structures of new triterpene glycosides, Gymnemosides- $c$, $-f$, $-e$ and $-f$, from the leaves ofthe Gymnema sylvestre R.Br.: Influence of Gymnemaglycosides on glucose uptake inrat's small intestinal fragments. Chem Pharm Bull. 1997;45(12):2034-8.

45. Kurihara, Y. Characteristics of antisweet substances, sweet proteins and sweetness inducing protein. Crit Rev Food Sci Nutr. 1992;32(3):231-52

46. Sugihara Y, Nojima H, Matsuda H, Murakami T, Yoshikawa M, Kimura I. Antihyperglycemic effects of gymnemic acid IV, a compound derived from Gymnema sylvestre leaves in streptozotocin-diabetic mice. Journal of Asian Natural Products Research. 2000;2(4):321-7.

47. Spasov AA, Samokhina MP, Bulanov AE. Antidiabetic properties of Gymnema sylvestre (a review). Pharm Chem J. 2008;42(11):626-9.

48. Kim HJ, Hong SH, Chang SH, et al. Effects of feeding a diet containing Gymnema sylvestre extract: Attenuating progression of obesity in C57BL/6J mice. Asian Pac J Trop Med. 2016;9(5):437-44

49. Marciani DJ, Press JB, Reynolds RC, et al. Development of semisynthetic triterpenoidsaponin derivatives with immune stimulating activity. Vaccine. 2000;18(27):3141-51.

50. Kazutaka M, Shigeo T, Tadashi F, Goro K, Shanti PU, Mitsunori K, et al. Isolation of Conduritol A from Gymnema sylvestre and its Effect against Intestinal Glucose Absorption in Rats. Biosc. 1993;57(12):2184-5.

51. Ninomiya Y, Imoto T. Gurmarin inhibition of sweet taste responses in mice. Am J Physiol. 1995;268(4):R1029-25.

52. Shimizu K, Ozeki M, lino A, Nakajyo S, Urakawa N, Atsuchi M. Structureactivity relationships of triterpenoid derivatives extracted from Gymnema inodorum leaves on glucose absorption. Japanese Journal of Pharmacology. 2001;86(2):223-9

53. Tsujikawa T, Kanauchi O, Andoh A, Saotome T, Sasaki M, Fujiyama Y, et al. Serum Concentrations of Trace Elements in patients with Crohn's Disease Receiving Enteral Nutrition. Nutr. 2003;19:137-9.

54. Salem SA, Hassan DR, Mowafy AR. A comparative impact of different types of a single antioxidant supplementation (B-carotene, alfa tocopherols and ascorbic acids) on lipid profile in hyperlipidemic rats. Middle-east J Sci Res. 2009;4:35460.

55. Trease GE, Evans WC. Pharmacognosy. $15^{\text {th }}$ Ed. Saunders Publishers, London 2002; 42-44, 221-229, 246-249, 304-306,331-332, 391-393.

56. Bhansali S, Shafiq N, Pandhi $P$, et al. Effect of a deacyl gymnemicacid on glucose homeostasis and metabolic parameters in arat model of metabolic syndrome. Indian J Med Res. 2013;137(6):1174-9.

57. Hanhineva K, Torronen R, Bondia-Pons I, Pekkinen J, Kolehmainen M, et al. Impact of dietary poly-phenols oncarbohydrate metabolism. Int J Mol Sci. 2010;11(4):1365-402.

58. Bahadoran Z, Mirmiran P, Azizi F. Dietary polyphenols as potential nutraceuticals in management of diabetes: a review. J Diabetes Metab Disord. 2013;12(1):1-9.

\section{GRAPHICAL ABSTRACT}

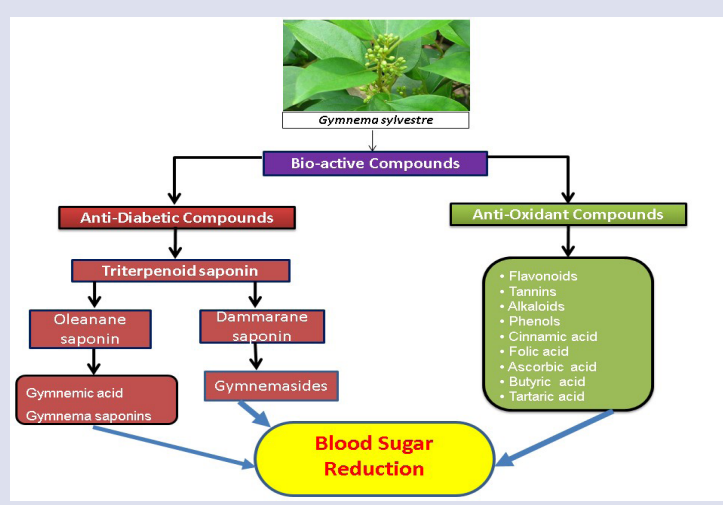

\section{SUMMARY}

- Gymnema sylvestre is commonly known as gurmar, a medicinally important plant in the treatment of Type 2 diabetes, belonging to the family Asclepiadaceae.

- Several active compounds like gymnemic acid, gymnema saponins (gymnemagenin, gymnestrogenin), gymnemasides, anthraquinones, flavones, hentriacontane, pentatriacontane, phytin, resins, tartaric acid, formic acid, butyricacid, lupeol and alkaloid like gymnamine etc. are responsible for antidiabetic properties.

- Due to the presence of flavonoids, cinnamic acid, folic acid, ascorbic acid etc. Gurmar leaves have high antioxidant activities. 


\section{ABOUT AUTHORS}

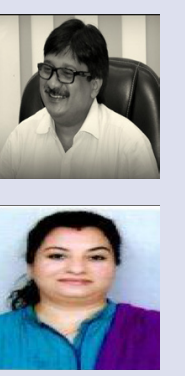

Dr. Santanu Paul is an Professor at the Department of Botany, University of Calcutta, India. He has experience in isolation and characterization of anti cancerous novel compounds from medicinal plants and looking at the molecular mechanism of apoptosis induction.

Suparna Laha is a Research Fellow at the Department of Botany, University of Calcutta, India.

Cite this article: Laha S, Paul S. Gymnema sylvestre (Gurmar): A Potent Herb with Anti-Diabetic and Antioxidant Potential. Pharmacog J. 2019;11(2):201-6. 